\title{
ISU AGAMA DALAM SISDIKNAS N0. 20 TAHUN 2003: MENINJAU KEMBALI JALAN DEMOKRASI PENDIDIKAN NASIONAL
}

\author{
Binsar A. Hutabarat \\ Reformed Center for Religion and Society
}

ABSTRACT: This article discusses religious issues and implementation of the National Education System Law (UndangUndang Sistem Pendidikan Nasional or Sisdiknas Law) No. 20 of 2003. The presence of Sisdiknas 2003 can not be separated from the power struggles that occur at the time. The ideological debate among the Indonesian elite had not ended, and caused crisis in managing education in Indonesia. As a result, the mobilization of educational resources to achieve the educational goals met some obstacles; one of them is on private education especially those established by religious institutions. The politics of education in Indonesia is still dominated by groups' interests. Consequently national education law has not appreciated the diversity of Indonesia, and has not become the property of all individuals and groups.

KEYWORDS: national education system (Sisdiknas), religious education, democracy education 
ABSTRAK: Tulisan ini akan membahas isu agama yang hadir pada saat penetapan Undang-undang Sistem Pendidikan Nasional (Sisdiknas) No 20 Tahun 2003, dan juga implementasinya. Kehadiran Sisdiknas 2003 ternyata tidak dapat dilepaskan dari pergulatan kekuasaan yang terjadi pada saat itu. Belum selesainya perdebatan ideologi di kalangan elite Indonesia itu menyebabkan terjadinya krisis manajemen pendidikan Indonesia. Akibatnya mobilisasi sumber daya pendidikan untuk mencapai tujuan pendidikan yang ditetapkan mengalami hambatan, salah satunya adalah masalah pendidikan swasta, khususnya yang didirikan lembaga agama. Politik pendidikan Indonesia masih dikuasai kepentingan kelompok. Akibatnya Undang-undang Pendidikan Nasional belum menghargai kemajemukan bangsa Indonesia, dan belum menjadi milik semua individu dan kelompok.

KATA KUNCI: sistem pendidikan nasional, pendidikan agama, pendidikan demokrasi

\section{PENDAHULUAN}

Undang-Undang Dasar 1945 secara tegas mengatakan, "Pemerintah mengusahakan dan menyelenggarakan suatu sistem pengajaran nasional yang ditetapkan dengan Undang-Undang." ${ }^{1}$ Pemerintah mendapatkan mandat rakyat untuk mengusahakan dan menyelenggarakan suatu sistem pendidikan nasional, itu

${ }^{1}$ Fuad Ihsan, Dasar-Dasar Kependidikan (Jakarta: Rineka Cipta, 2011), h.121. 
berarti, isi undang-undang sistem pendidikan nasional mesti mewakili seluruh aspirasi rakyat Indonesia.

Pada sisi lain, usaha mencerdaskan kehidupan bangsa melalui gerakan pendidikan nasional Indonesia bukan hanya dilakukan oleh pemerintah melalui pendirian sekolah-sekolah negeri, tetapi juga keterlibatan pendidikan swasta yang amat strategis untuk suksesnya program tersebut, khususnya sekolahsekolah yang didirikan lembaga-lembaga keagamaan. Apalagi, jauh sebelum kemerdekaan, pendidikan agama di negeri ini telah berpartisipasi aktif dalam usaha mencerdaskan kehidupan bangsa melalui pendirian sekolah-sekolah agama. Bahkan, bisa dikatakan, tanpa partisipasi lembaga-lembaga keagamaan dengan sekolahsekolah agamanya yang tersebar di seantero negeri ini, kewajiban pemerintah untuk memberikan pendidikan yang layak bagi segenap rakyat Indonesia sebagaimana perintah konstitusi tidak mungkin tercapai, setidaknya sebagaimana pencapaian saat ini.

Jasa yang teramat besar dari pendidikan swasta kultural dan pendidikan swasta agama pada masa kini makin terpinggirkan, khususnya setelah lahirnya Sisdiknas 1989 dan puncaknya pada Sisdiknas 2003. Pendidikan swasta tidak lagi bebas mendirikan sekolah-sekolah agama dalam keunikannya, campur tangan pemerintah dalam ruang privat sekolah swasta khususnya pendidikan agama terlihat jelas dalam Sisdiknas 2003. Peninjauan ulang terhadap Sisdiknas 2003 ini sangat diperlukan untuk membebaskan pendidikan keagamaan dari kungkungan demi suksesnya gerakan pendidikan nasional Indonesia. 


\section{ISU AGAMA DALAM GERAKAN PENDIDIKAN NASIONAL}

Pentingnya gerakan pendidikan nasional telah disadari para pemimpin pergerakan Indonesia jauh sebelum hadirnya Negara Kesatuan Republik Indonesia (NKRI). Sejak kebangkitan nasional tahun 1908 para pemimpin pergerakan kebangsaan menyadari, bahwa pendidikan merupakan kendaraan penting untuk membebaskan rakyat Indonesia dari kekuasaan penindasan. Melalui pendidikan berkualitas manusia Indonesia dapat menjadi manusia yang cerdas dan berbudaya. Menyadari pentingnya gerakan pendidikan nasional itu, salah seorang pemimpin Budi Utomo, yaitu Ki Hajar Dewantara kemudian mengubah perjuangan politiknya melalui pendidikan nasional. Penjajah Belanda tidak mungkin dapat memecah belah rakyat Indonesia untuk terus melanggengkan kekuasaannya apabila masyarakat Indonesia telah cerdas. Rakyat Indonesia yang cerdas pasti akan menyadari bahwa hanya dengan persatuan seluruh rakyat Indonesia penjajahan di bumi Indonesia dapat dilenyapkan. ${ }^{2}$

Pemahaman Dewantara yang mendalam tentang pendidikan didapatnya selama berada dalam pembuangan di Belanda. Tahun 1913, Ki Hajar Dewantara berupaya untuk mendalami masalah pendidikan dengan memperkuat teori-teori pendidikan di Barat. Selanjutnya, tahun 1920 ia mulai mempraktikkan teori pendidikan yang diperolehnya itu, disesuaikan dengan kebutuhan bangsa Indonesia yaitu antara lain sebagai alat untuk menumbuhkan rasa

2 Soedijarto, Landasan dan Arah Pendidikan Nasional (Jakarta: Kompas, 2008), h.14. 
kebangsaan. Upaya tersebut dilakukannya dengan mendasarkan pendidikan nasional pada kebudayaan Indonesia. Melalui kebudayaan Indonesia dapat dilahirkan nasionalisme Indonesia yang akan menjadi alat untuk menantang kekuasaan kolonialisme Belanda. ${ }^{3}$

Pemahamannya yang mendalam, serta perjuangannya yang begitu nyata dalam gerakan pendidikan nasional utamanya melalui Sekolah Taman Siswa, membawa Dewantara berhasil menduduki jabatan Menteri Pengajaran Pendidikan dalam kabinet pertama Indonesia. Tidak cukup sampai di situ peran Ki Hajar Dewantara dalam gerakan pendidikan nasional Indonesia juga terlihat pada posisi strategis yang dijabatnya terkait dengan pendidikan nasional. Pada tahun 1946 Dewantara mengetuai panitia penyelidik pengajaran, yang dibentuk pemerintah untuk menentukan garis-garis baru di bidang pendidikan dan pengajaran sesuai dengan cita-cita bangsa Indonesia. Kemudian, tahun 1948 ia mengetuai Badan Penasihat Pembentukan Undangundang yang menempatkan dasar-dasar bagi pendidikan dan pengajaran. Cita-cita dan pemikiran besar Dewantara tercermin dalam pendidikan dan pengajaran yang diselenggarakan Republik Indonesia dan dalam Undang-Undang nomor 4/1950 tentang dasar-dasar pendidikan dan pengajaran di sekolah. ${ }^{4}$ Mengingat

${ }^{3}$ H.A.R Tilaar, "Pedagogik Kritis: Perkembangan, Substansi, dan Perkembangannya di Indonesia, dalam Pedagogik Kritis," dalam Pedagogik Kritis ed. H.A.R Tilaar et al. (Jakarta: Rineka Cipta, 2011), h. 44.

${ }^{4}$ Lihat Ensiklopedi Nasional Indonesia (Jakarta: Delta Pamungkas), h. 329- 
jasanya yang besar dalam merintis pendidikan Nasional Indonesia Dewantara dianugerahi kehormatan sebagai Bapak Pendidikan Nasional, dan hari kelahirannya (2 Mei) dijadikan Hari Pendidikan Nasional.(Surat Keputusan Presiden RI No. 305 Tahun 1959, tanggal 28 November 1959). Ia meninggal dunia di Yogyakarta tanggal 26 April 1959 dan dimakamkan di Taman Wijaya Brata.

Sebelum kemerdekaan para pemimpin pergerakan Indonesia menempatkan pendidikan nasional sebagai unsur esensial bagi lahirnya generasi muda yang tinggi kadar rasa kebangsaannya, karena untuk menghadapi penjajah yang begitu lama menguasai negeri ini dibutuhkan pemuda-pemuda yang cerdas dan memiliki semangat nasionalisme yang tinggi. Manusia Indonesia yang cerdas pastilah memahami bahwa persatuan bangsa dibutuhkan untuk menghancurkan kekuasaan penjajah. Gerakan pendidikan nasional yang menekankan pada gerakan kebudayaan itu terlihat pada berdirinya Budi Utomo, Sekolah Taman Siswa, Kayutanam, Muhammadiyah, dll.

Setelah kemerdekaan, para pendiri republik menyadari bahwa setelah runtuhnya Sriwijaya dan Majapahit Nusantara menjadi puluhan kerajaan kecil bersifat kedaerahan yang mengatur daerahnya sendiri. Negara-negara kecil yang tersebar di bumi Nusantara itu juga belum tersentuh peradaban modern karena selama 350 tahun berada dalam kungkungan penjajah. Nasionalisme Indonesia yang melahirkan Indonesia sebagai negara merdeka yang baru di bawah Pancasila semestinya 
melahirkan masyarakat baru, dan pembangunan pendidikan sebagai subsistem pembangunan nasional harusnya berfungsi memperkuat kohesi sosial Indonesia yang amat beragam itu, sehingga Masyarakat Pancasila bukan lagi masyarakat-masyarakat lama yang terpisah-pisah sebagaimana yang ada sebelum kemerdekaan. Para pendiri bangsa pada waktu itu menyadari bahwa Indonesia harus menjadi negara bangsa yang maju, adil makmur dan sejahtera berdasarkan Pancasila, untuk itu maka para pendiri bangsa ini menetapkan bahwa "mencerdaskan kehidupan bangsa" merupakan tugas pemerintah negara Republik Indonesia.

Selama pemerintahan orde lama, pembangunan nasional Indonesia, termasuk bidang pendidikan tidak mengalami kemajuan berarti, hal ini terjadi karena selama itu Indonesia bukan saja harus berjuang mempertahankan kemerdekaan dari serbuan Belanda yang ingin kembali menjajah Indonesia, tetapi juga pemerintah Indonesia disibukkan menghadapi pemberontakanpemberontakan yang tersebar di beberapa daerah, dan juga mengalami tiga belas kali pergantian kabinet yang tentu saja menghambat lajunya pembangunan nasional.

Pada era orde baru penyelenggaraan pendidikan nasional untuk mencerdaskan kehidupan bangsa menjadi sekadar memperluas kesempatan belajar tanpa memperhatikan persyaratan minimal yang harus dipenuhi bagi penyelenggaraan pendidikan yang dapat mencerdaskan kehidupan bangsa dan memajukan kebudayaan nasional. Sekolah-sekolah Inpres yang tersebar di berbagai pelosok negeri ini adalah potret pendidikan yang mengutamakan kesempatan belajar dengan minim fasilitas 
dan kualitas. Pemandangan perihal kondisi sekolah yang minim, mulai dari kualitas guru yang tidak memadai, sampai pada fasilitas pendidikan yang amat minim sangat mudah dijumpai, khususnya di pelosok-pelosok negeri ini. Penelitian UNESCO pada tahun 1996 menemukan bahwa mutu pendidikan semacam ini, yang umumnya terdapat di negara berkembang seperti Indonesia, bukan hanya tidak bermakna bagi pencerdasan kehidupan bangsa tetapi sebaliknya akan melahirkan masalah baru bagi bangsa tersebut. ${ }^{5}$

Pada era orde baru, target kuantitas memang tercapai, namun target kualitas belum tercapai. Penguasaan, pengembangan, dan pemanfaatan teknologi untuk meningkatkan taraf kehidupan masyarakat masih jauh tertinggal dibandingkan negara-negara tetangga seperti Korea Selatan, Malaysia dan Singapura. Isu-isu kritis yang belum selesai yang menghambat lajunya pendidikan Indonesia terjadi hampir menyeluruh, baik dalam persoalan manajemen pendidikan, kurikulum dan sistem evaluasi pendidikan yang terlihat jelas dalam sistem ujian nasional.

Dalam penyelenggaraan pendidikan nasional, pemerintah Indonesia telah menetapkan tiga undang-undang pendidikan,

5 Soedijarto, "Pancasila Sebagai Filsafat Dasar dan Ideologi Negara Kebangsaan Indonesia dan Implikasinya terhadap Penyelenggaraan Sistem Pendidikan Nasional", (Makalah dalam seminar nasional bertemakan Pancasila dan Sistem Pendidikan Nasional, oleh PPA Gerakan Mahasiswa Nasional Indonesia, Jakarta, 24 Juni 2011). 
yaitu UU No. 4 Tahun 1950 Jo UU No. 12 tahun 1954, UU No. 2 Tahun 1989 Tentang pendidikan nasional, dan UU No. 20 tahun 2003 di samping UU No. 20 tahun 1961 tentang Perguruan Tinggi. Namun, setelah penetapan Undang-undang Pendidikan Nasional 1989 dan puncaknya Sisdiknas 2003, penyelenggaraan pendidikan nasional Indonesia bisa dikatakan kehilangan arah. Pergulatan kekuasaan yang menyentuh dimensi ideologis kemudian membuat undang-undang sistem pendidikan nasional tidak konsisten berpegang pada Pancasila dan UUD 45. Bahkan prinsipprinsip yang telah dibangun oleh bapak Pendidikan Nasional Indonesia, Ki Hajar Dewantara yang tercermin dalam Undangundang Pendidikan 1950 juga diabaikan.

Sejak kemerdekaan di Indonesia dikenal tiga jenis pengelola persekolahan: Pertama, sekolah swasta konvensional yang didirikan oleh lembaga keagamaan dan diajarkan pelajaran agama menurut keyakinan sekolah itu. Kedua, Sekolah-sekolah swasta non-konfesional, yang tidak berafiliasi pada satu lembaga keagamaan manapun (Taman Siswa, Persatuan Guru Republik Indonesia (PGRI). Ketiga, sekolah-sekolah negeri yang dikelola oleh pemerintah. Di sekolah jenis kedua dan ketiga diberikan pelajaran agama menurut agama masing-masing, sedang pada sekolah jenis pertama hanya mengajarkan pelajaran agama yang diyakini lembaga penyelenggara sekolah itu. ${ }^{6}$

${ }^{6}$ Lihat N.K. Atmadja Hadinoto, Dialog dan Edukasi (Jakarta: BPK Gunung Mulia, 1999), h. 157. 
Undang-Undang Pendidikan Nasional No. 4 Tahun 1950 hanya berlaku untuk sekolah-sekolah negeri dan tidak berlaku untuk sekolah-sekolah agama dan pendidikan masyarakat. Pemberlakuan undang-undang ini ditetapkan dalam UndangUndang No. 12 Tahun 1954, empat tahun setelah diundangkan. Tujuan dari pendidikan dan pengajaran menurut pasal 3 dalam undang-undang ini ialah membentuk manusia susila yang cakap dan warga negara yang demokratis serta bertanggung jawab tentang kesejahteraan masyarakat dan tanah air. Pasal 4 menjelaskan Pendidikan dan Pengajaran berdasar atas asas-asas yang termaktub dalam Pancasila, Undang-Undang Dasar Negara Republik Indonesia dan atas kebudayaan kebangsaan Indonesia. Pasal 13 undang-undang ini menetapkan bahwa: Atas dasar kebebasan tiap-tiap warga negara menganut sesuatu agama atau keyakinan hidup, maka kesempatan leluasa diberikan untuk mendirikan dan menyelenggarakan sekolah-sekolah partikelir. Sekolah partikelir ini berhak melakukan pendidikan dan pengajaran yang sesuai dengan paham masing-masing, jadi pemerintah menghargai ruang privat sekolah swasta dan sekolah agama. Selanjutnya, belajar di sekolah agama yang telah mendapat pengakuan dari Menteri Agama dianggap telah memenuhi kewajiban belajar (pasal 10 ayat 2). Pasal 14 berbunyi, Sekolahsekolah swasta yang memenuhi syarat-syarat, dapat menerima subsidi dari pemerintah untuk pembiayaannya. Mengenai pelajaran agama di sekolah-sekolah negeri pasal 20 menjelaskan: dalam sekolah-sekolah negeri diadakan pelajaran agama, orang tua murid menetapkan apakah anaknya akan mengikuti pelajaran 
agama tersebut. Bagian penjelasan pasal ini menegaskan bahwa pelajaran agama tidak mempengaruhi kenaikan kelas. ${ }^{7}$

Dalam hal pendidikan agama di sekolah pada awalnya pemerintah Indonesia amat menghargai kebebasan masyarakat untuk menyelenggarakan pendidikan sesuai dengan keunikan kelompok masyarakat atau agamanya, bahkan pemerintah memberikan subsidi kepada sekolah-sekolah itu, mengenai hal itu Dewantara menjelaskan:

Kini sudah menjadi keinsyafan umum, bahwa adalah negara yang demokratis adanya, sekolah-sekolah partikelir itu dianggap perlu. Tidak hanya semata-mata membantu usaha pemerintah guna pengluasan pendidikan dan pengajaran, namun atas dasar dan pertimbangan, bahwa tiap aliran ideologis, baik yang bertali dengan keyakinan, kebatinan' maupun kemasyarakatan, berhak untuk memelihara usaha pendidikan dan pengajaran yang didasarkan atas keyakinan atau kepercayaan masing-masing. Dalam pandangan itu tiap-tiap sekolah yang memakai dasar khusus itu tidak hanya berhak untuk ada, namun pula berhak untuk mendapat subsidi, karena sebetulnya mereka itu melakukan pekerjaan yang semestinya harus dilakukan oleh pemerintah. Sejak bangsa kita menjadi bangsa yang merdeka, maka makin lama makin luaslah keinsyafan, bahwa sekolah partikelir itu sangat perlu untuk pembangunan pada umumnya. Yang tiap orang dapat mudah mengerti ialah tidak mungkinnya pemerintah mencukupi

7 Undang-Undang No 4 Tahun 1950 (Menteri Pendidikan, Pengajaran dan Kebudayaan). 
kebutuhan rakyat akan belajar dan bersekolah, jika tidak dibantu oleh sekolah-sekolah partikelir. Lain daripada itu lambat laun para ahli kenegaraan menginsyafi juga bahwa dalam negara yang demokratis dan mengutamakan hak-hak asasi manusia, harus ada kesempatan yang sebesar-besarnya bagi tiap-tiap golongan yang berideologi, untuk mendirikan sekolah-sekolah guna memelihara cita-cita kebatinannya itu. Bahwa hal ini kini telah diakui oleh pemerintah, dapat dibuktikan dengan adanya kesanggupan dari pihak Kementerian P.P dan K untuk memberi subsidi kepada sekolah-sekolah partikelir pada umumnya. ${ }^{8}$

Kebebasan lembaga agama untuk mendirikan sekolah-sekolah agama adalah bagian dari hak-hak asasi manusia, karena itu pemerintah tidak boleh masuk ke dalam ruang privat agama, kecuali dalam hal menjaga mutu sekolah-sekolah agama itu, dan itu pun untuk hal-hal yang terkait dengan ketertiban dan keamanan umum:

Tiap-tiap sekolah partikelir sebenarnya melakukan pekerjaan, yang sebetulnya adalah kewajiban pemerintah. (Dengan bantuan sekolah-sekolah partikelir tadi pemerintah dapat mempercepat datangnya saat, seperti termaksud dalam UUD, bahwa tiap-tiap warga negara tidak saja berhak untuk mendapat pengajaran, namun benar-benar mendapat pengajaran. Karena itu maka sebenarnya pemerintah wajib untuk tiap-tiap anak yang bersekolah di sekolah partikelir itu, mengeluarkan biaya yang

${ }^{8}$ Ki Hajar Dewantara , Pendidikan ( Yogyakarta: Perguruan Taman Siswa, 2000), h. 203. 
sama dengan biaya bagi anak-anak yang bersekolah di sekolah negeri. Janganlah dalam peraturan subsidi itu termuat syaratsyarat pembatasan selain yang bertali dengan ketertiban dan keamanan umum serta pemeliharaan mutu pengajaran. Dalam hal ini pemerintah berhak dan wajib mengawasi usaha sekolahsekolah partikelir tersebut. Misalnya dengan mengadakan pemeriksaan tetap, dengan mengadakan, ujian negeri, dan lainlain sebagainya, tetapi jangan mencampuri urusan dalam (yang khusus atau istimewa). Janganlah memaksakan kepada sekolahsekolah partikelir sesuatu peraturan yang diwajibkan untuk sekolah-sekolah negeri, selain yang bertali dengan pertanggungjawaban tata usaha. Tentang pemeliharaan ketertiban dan keamanan umum hendaknya diingat isi UUD yang mengenai kebebasan warga negara dalam hal-hal yang biasa disebut, hakhak asasi. Pemerintah memang berkewajiban menyelenggarakan sekolah-sekolah umum di tempat-tempat yang membutuhkannya, akan tetapi anggapan perlu atau tidaknya ada sekolah partikelir, itu harus diserahkan kepada golongan-golongan khusus, yang berkepentingan dan yang berhak mendirikan sekolah-sekolah khusus, (Islam, Kristen, Katolik dan sebagainya) untuk memelihara ideologinya masing-masing. Terhadap sekolah khusus ini pemerintah hanya melakukan penilikan dan tuntunan untuk menjaga, jangan sampai sekolah-sekolah khusus tadi bermutu rendah atau menyalahi syarat-syarat ketertiban dan keamanan umum. ${ }^{9}$

${ }^{9}$ Dewantara, Pendidikan, h. 234. 
Pada waktu kemudian, kebebasan lembaga agama untuk menetapkan kebijakannya pada sekolah-sekolah agama itu kemudian mengalami hambatan. Penghambatan itu mulai terlihat sejak diluncurkannya Sisdiknas tahun 1989. Pemerintah pada waktu itu menginginkan pengaturan pendidikan yang lebih ketat dengan alasan untuk memperkuat ketahanan nasional dan sayangnya itu mengabaikan potensi kemajemukan. Mengenai hal itu Fuad Hassan, menteri pendidikan pada waktu itu melalui kritiknya terhadap Undang-undang Pendidikan Tahun 1950:

Undang-undang tentang Dasar-dasar pendidikan dan pengajaran di sekolah yang disahkan tahun 1950 adalah undang-undang yang secara khusus mengatur pendidikan dan pengajaran di Sekolah Taman Kanak-kanak, Sekolah Dasar dan Sekolah Menengah. Pasal 2 dari undang-undang tersebut dengan jelas menyatakan bahwa undang-undang ini tidak berlaku untuk pendidikan dan pengajaran di sekolah-sekolah agama dan pendidikan masyarakat. ${ }^{10}$

Lebih lanjut Fuad Hassan menjelaskan:

Dalam Rancangan Undang-Undang tentang tujuan pendidikan nasional dinyatakan dengan tegas bahwa salah satu tujuan sistem pendidikan nasional adalah "Peningkatan ketaqwaan terhadap Tuhan Yang Maha Esa". Ini berarti bahwa dalam pengaturan penyelenggaraan pendidikan semua peserta didik harus memperoleh pendidikan agama, karena bilamana ada peserta

10 Weinata Sairin, Himpunan Peraturan di Bidang Pendidikan (Jakarta: BPK Gunung Mulia, 1999), h. 6. 
didik yang tidak memperoleh pendidikan agama, apa yang dinyatakan sebagai tujuan sistem pendidikan nasional, yaitu peningkatan "ketaqwaan terhadap Tuhan Yang Maha Esa"tidak mungkin dapat terwujud. ${ }^{11}$

Apabila dalam Undang-undang Pendidikan Nasional Tahun 1950 sekolah swasta agama dibedakan dengan sekolah negeri, keunikannya dihargai, dan pemerintah juga tidak mencampuri ruang privat sekolah agama, maka dalam Sisdiknas tahun 1989 kedua sekolah yang pada hakikatnya berbeda itu kemudian disamakan. Penyamaan akan kedua pendidikan itu secara bersamaan juga melegitimasikan pemerintah untuk campur tangan dalam penetapan kebijakan sekolah agama, antara lain dengan mewajibkan agar sekolah agama memberikan pelajaran agama sesuai dengan agama yang dipeluk siswa yang ada. Pelajaran agama yang awalnya dibebaskan dan tidak mempengaruhi kelulusan, dalam Sisdiknas 1989 dan Sisdiknas 2003 dipaksakan dan mempengaruhi kelulusan. Dalam hal ini jelas, bahwa Sisdiknas 2003 memiliki semangat yang berbeda dengan Undang-undang Pendidikan Tahun 1950. Sisdiknas 2003 mengabaikan hak-hak dari kelompok agama yang ada di Indonesia dan membatasi kebebasan agama-agama itu untuk membangun pendidikan sesuai keyakinan kelompok agama itu. ${ }^{12}$

11 Sairin, Himpunan Peraturan di Bidang Pendidikan, h.22.

12 Berlainan dari Undang-undang tentang Dasar-dasar Pendidikan dan Pengajaran di Sekolah tahun 1950 dan Undang-Undang tentang Pendidikan Nasional diusahakan sedapat mungkin menghilangkan pembedaan antara perguruan negeri dan swasta. Pada hakikatnya kedua jenis perguruan ini harus 
Hegemoni kelompok-kelompok yang ingin memaksakan Indonesia sebagai negara agama jelas terlihat dalam undangundang Sisdiknas 2003 yang memakai tangan negara untuk membatasi kebebasan kelompok agama lain. Penekanan tujuan pendidikan dari mencerdaskan kehidupan bangsa menjadi manusia yang beriman dan bertaqwa kepada Tuhan Yang Maha Esa serta akhlak mulia sebenarnya tidak menjadi persoalan, karena semua orang Indonesia adalah beragama, namun hal itu menjadi persoalan ketika pasal-pasal dalam undang-undang tersebut kemudian dijadikan alat untuk merampas hak sekolahsekolah agama mendirikan sekolah-sekolah yang didasarkan landasan teologi agama itu. Sila Ketuhanan yang Maha Esa ditafsirkan secara teologis, dan tragisnya agama-agama kebudayaan tidak lagi mendapat tempat dalam sekolah-sekolah negeri, agama-agama diluar agama-agama besar harus rela mengabil pelajaran agama yang berbeda dengan apa yang diyakininya, apalagi kemudian pelajaran agama yang awalnya tidak dipaksakan dan tidak menentukan kelulusan, pada Sisdiknas itu masuk dalam kurikulum inti dan menentukan kelulusan. Penetapan Sisdiknas yang mewajibakan pelajaran agama jelas memperlihatkan semangat Piagam Jakarta yang ingin mengembalikan tujuh kata yang hilang, yakni, "dengan menjalankan syariat Islam bagi pemeluk-pemeluknya." Mengenai kontroversi sekitar Sisdiknas 2003, H.A.R. Tilaar menyimpulkan:

dianggap sama dan diperlakukan sama. Sairin, Himpunan Peraturan di Bidang Pendidikan, h. 25. 
"Lahirnya NKRI harus diakui tidak bebas dari pergulatan kekuasan (power) yang terjadi ketika pembentukan Negara Republik Indonesia tahun 1945 dengan adanya perdebatan kelompok agama dan kelompok non agama, kelihatannya lahir kembali di dalam UU No. 20 tahun 2003 itu."13

Kontroversi tentang Sisdiknas 2003 yang kemudian mengemuka menjadi persoalan agama dapat dipahami dengan apa yang dinyatakan dalam undang-undang tersebut:

Pembukaan undang-undang Sisdiknas menyatakan bahwa Undang-Undang Dasar Negara Republik Indonesia Tahun 1945 mengamanatkan Pemerintah mengusahakan dan menyelenggarakan satu sistem pendidikan nasional yang meningkatkan keimanan dan ketakwaan kepada Tuhan Yang Maha Esa serta akhlak mulia dalam bangsa yang diatur dengan undang-undang; Pasal 1 (Sisdiknas 2003) menyatakan bahwa Dalam undang- undang ini yang dimaksud dengan Pendidikan adalah usaha sadar dan terencana untuk mewujudkan suasana belajar dan proses pembelajaran agar peserta didik secara aktif mengembangkan potensi dirinya untuk memiliki kekuatan spiritual keagamaan, pengendalian diri, kepribadian, kecerdasan, akhlak mulia, serta keterampilan yang diperlukan dirinya, masyarakat, bangsa dan negara. Pendidikan nasional adalah pendidikan yang berdasarkan Pancasila dan Undang-Undang Dasar Negara Republik Indonesia Tahun 1945 yang berakar pada nilai-nilai agama, kebudayaan nasional Indonesia dan tanggap

13 Tilaar, "Pedagogik Kritis", h.50 
terhadap tuntutan perubahan zaman. Pasal 3 menyatakan bahwa Pendidikan nasional berfungsi mengembangkan kemampuan dan membentuk watak serta peradaban bangsa yang bermartabat dalam rangka mencerdaskan kehidupan bangsa, bertujuan untuk berkembangnya potensi peserta didik agar menjadi manusia yang beriman dan bertakwa kepada Tuhan Yang Maha Esa, berakhlak mulia, sehat, berilmu, cakap, kreatif, mandiri, dan menjadi warga negara yang demokratis serta bertanggung jawab. Pasal 12 (1) Setiap peserta didik pada setiap satuan pendidikan berhak mendapatkan pendidikan agama sesuai dengan agama yang dianutnya dan diajarkan oleh pendidik yang seagama; ${ }^{14}$

Dengan penetapan tersebut, maka sekolah-sekolah swasta dan sekolah-sekolah agama tidak lagi memiliki kebebasan untuk menyelenggarakan pendidikan dan menyusun kurikulum berdasarkan keunikan kelompok agama yang ada. Konsekuensi dari rumusan tujuan pendidikan yang lebih agamis itu adalah munculnya rumusan pasal 12 ayat(1) butir(a) yang menyatakan bahwa, "Setiap peserta didik pada setiap satuan pendidikan berhak mendapatkan pendidikan agama sesuai dengan agama yang dianutnya dan diajarkan oleh pendidik yang seagama. Rumusan tersebut berbenturan dengan filosofis sekolah-sekolah swasta yang bercirikan agama. Padahal, pendirian sekolah-sekolah tersebut sejak awal disadari sebagai bagian dari siar atau misi keagamaan sehingga secara otomatis aturan-aturan di dalamnya

${ }^{14}$ Undang-Undang Sisdiknas No 20 Tahun 2003. 
adalah sesuai dengan agama yang dianut oleh para pendirinya. ${ }^{15}$

Pemaksaan pelajaran agama yang berbeda di sekolah agama tertentu jelas menunjukkan adanya pergulatan kekuasaan pada waktu penetapan Sisdiknas 2003. Sekolah-sekolah Kristen banyak diminati oleh mereka yang beragama lain, dan karena itu muncul semangat untuk membatasi misi sekolah-sekolah Kristen tersebut, yakni dengan memaksakan pelajaran agama yang berbeda pada sekolah-sekolah-sekolah agama. Jadi, keunikan sekolah agama tidak lagi diakui, dan ini dilakukan untuk membendung misi agama yang ada pada sekolah-sekolah agama itu.

Hadirnya Undang-undang Sisdiknas Nomor 20 Tahun 2003 telah mempengaruhi eksistensi pendidikan agama di negeri ini, khususnya pendidikan dasar dan menengah yang bernapaskan agama. Keharusan sekolah pendidikan bernapaskan agama menyediakan guru-guru agama berdasarkan agama yang dipeluk siswa sebagaimana ditetapkan dalam UU Sisdiknas 2003 membuat sekolah-sekolah agama itu mengatur siasat untuk menolak kehadiran siswa yang berbeda agama. Jika pada masa lalu pluralitas masih mewarnai sekolah- sekolah swasta berdasarkan agama, maka kini menjadi sesuatu yang langka.

Tujuan pendidikan yang awalnya adalah mencerdaskan kehidupan bangsa, bergeser penekanannya kepada keberimanan dan ketaqwaan kepada Tuhan Yang Maha esa, serta akhlak mulia, ironisnya, dampak dari implementasi Sisdiknas tersebut

15 Darmaningtyas, "Mencari Sistem Pendidikan Nasional", dalam Education for Change, ed. Elika Dwi Muwarni et al., (Jakarta:BPK Gunung Mulia, 2010), h.21-22. 
kemudian menjadikan sekolah-sekolah negeri menjadi tidak netral, dan pemeluk agama minoritas yang memiliki cukup dana lebih memilih memasukkan anaknya pada sekolah swasta bernapaskan keagamaan, sedang mereka yang tidak mempunyai dana, harus rela menerima diskriminasi. Dampak implementasi Sisdiknas 2003 terhadap pendidikan di negeri ini dilukiskan oleh Darmaningtyas demikian:

Pada masa lalu sekolah negeri menjadi pilihan pertama bagi mereka yang ingin menyekolahkan anak tanpa hambatan terhadap agama yang dianutnya karena sekolah negeri merupakan simpul dari pluralisme: semua pemeluk agama diwadahi dan diperlakukan sama disana. Mereka yang ingin menyekolahkan anaknya dengan tujuan memperkuat keimanan, memilih sekolah swasta yang berbasis agama sesuai dengan agamanya. Banyak orang tua yang menyekolahkan anaknya ke sekolah-sekolah swasta yang berbeda dengan agama yang dianutnya karena semata-mata sekolah swasta tersebut dikenal baik mutunya. Ironisnya kondisi sekolah negeri sekarang justru membuat kaum minoritas (di daerahnya) memilih sekolah-sekolah swasta yang sesuai dengan agamanya karena sekolah negeri tidak lagi dipandang netral atau menjamin pluralitas bangsa. Akibatnya, tanpa disadari, kebijakan pendidikan pascareformasi ini justru menarik orang ke dalam kelompoknya masing-masing. Masyarakat pun kemudian terkotak-kotak berdasarkan agama yang dianutnya. Padahal, sekolah, terlebih sekolah negeri, mestinya menjadi ruang terbuka bagi siapa saja untuk membangun interaksi sosial demi membangun integrasi bangsa 
yang lebih kuat. Ironisnya kondisi sekolah negeri sekarang justru membuat kaum minoritas (di daerahnya) memilih sekolah-sekolah swasta yang sesuai dengan agamanya karena sekolah negeri tidak lagi dipandang netral atau menjamin pluralitas bangsa. Akibatnya, tanpa disadari, kebijakan pendidikan pascareformasi ini justru menarik orang ke dalam kelompoknya masing-masing. Masyarakat pun kemudian terkotak-kotak berdasarkan agama yang dianutnya. Padahal, sekolah, terlebih sekolah negeri, mestinya menjadi ruang terbuka bagi siapa saja untuk membangun interaksi sosial demi membangun integrasi bangsa yang lebih kuat. ${ }^{16}$

Mengutip apa yang dikatakan Paulo Freire, "Setiap proyek pendidikan bersifat politis dan penuh ideologi.Masalahnya adalah untuk kepentingan atau menentang kepentingan siapa politik pendidikan itu diarahkan."17 Pendidikan nasional Indonesia kehilangan arah, karena tidak konsistennya elite di negeri ini untuk berpegang pada Pancasila sebagai ideologi negara dan UUD 45. Politik pendidikan nasional belum diarahkan pada kebutuhan seluruh rakyat Indonesia, dan masih melayani kepentingan tertentu. Itulah sebabnya nasionalisme Indonesia terus tergerus. ${ }^{18}$ Tepatlah apa yang dikatakan Tilaar, "Pendidikan nasional telah

16 Darmaningtyas, "Mencari Sistem Pendidikan Nasional", h. 21.

17 Paulo Freire, Pendidikan Masyarakat Kota (Yogyakarta: LKIS, 2003), h. 31.

18 Secara politik, fungsi umum pendidikan nasional tentunya untuk menumbuhkan rasa nasionalisme yang sehat pada setiap sikap dan cara berpikir anak Indonesia. H.A.R. Tilaar, Manajemen Pendidikan Nasional (Bandung: Remaja Rosdakarya, 2011), h. 203. 
mengkhianati cita-cita Proklamasi 1945 yaitu ingin mewujudkan suatu bangsa Indonesia yang besar yang mendiami Nusantara yang terdiri dari bermacam suku bangsa tetapi yang bertekad satu, hidup bersama di dalam masyarakat Indonesia. Dewasa ini yang tampak adalah sebaliknya, pendidikan nasional bukan lagi pemersatu bangsa tetapi telah merupakan ajang pertikaian dan persemaian manusia-manusia yang berdiri sendiri dalam arti yang sempit." 19

\section{DISKRIMINASI TERHADAP SEKOLAH SWASTA DAN SEKOLAH AGAMA}

Perubahan undang-undang memang diperlukan untuk menjawab perubahan jaman, namun prinsip-prinsip dasar pendidikan yang meupakan jati diri bangsa Indonesia mestinya tidak bisa diabaikan begitu saja. Pengabaian terhadap jati diri masyarakat Indonesia yang beragam yang kemudian melahirkan diskriminasi terhadap sekolah-sekolah keagamaan yang berjasa besar dalam pembangunan pendidikan nasional terlihat jelas pada Sisdiknas 1989 dan puncaknya Sisdiknas 2003 yang menjadi bahasan utama tulisan ini.

Sebagaimana telah dijelaskan di atas, bahwa Undangundang Pendidikan Nasional Tahun 1950 merupakan cermin pemikiran bapak pendidikan nasional, Ki Hajar Dewantara, maka semestinya undang-undang yang disusun selanjutnya juga tidak

19 H.A.R. Tilaar, Standarisasi Pendidikan Nasional (Jakarta: Rineka Cipta, 2006), h.14. 
melupakan prinsip-prinsip dasar yang telah dibangun sebelumnya, khususnya dalam hal-hal yang berkaitan dengan agama yang telah dipikirkan secara serius pada waktu sebelumnya.

Apabila pemerintah masa kini cukup bijaksana untuk belajar dari masa lalu, maka diskriminasi terhadap sekolah-sekolah swasta agama tidak perlu terjadi. Penghargaan terhadap pendidikan agama pada masa lalu jelas terlihat dari apa yang dikatakan Dewantara:

Meskipun sifat, bentuk, dan laku pendidikan dan pengajaran itu pada dasarnya menjadi hak dan kewajiban tiap-tiap orang tua terhadap anaknya, namun dalam praktiknya tidak mungkin tiaptiap orang tua menyelenggarakan sendiri segala usaha pendidikan dan pengajaran bagi anak-anaknya tadi, dan terpaksalah mereka itu mempersatukan diri dengan orang-orang, yang bersamaan atau hampir bersamaan aliran hidupnya, untuk bersama-sama mewujudkan sistem pendidikan dan pengajaran sebagai suatu golongan yang khusus; berdirilah dengan begitu "sekolah partikelir" yang disebut private school (Inggris) atau juga bijzondere school (Belanda). Karena hak mendidik dan mengajar itu prinsipil ada pada orang tua, sedangkan kewajiban menyelenggarakannya adalah kewajiban negara, maka segala biaya yang umum dari sekolah partikelir itu sebetulnya harus ditanggung oleh pemerintah menurut peraturan keuangan yang sama dengan sekolah negeri; biaya-biaya yang dipikul oleh masing-masing badan yang menyelenggarakan pendidikan dan 
pengajaran yang khusus. ${ }^{20}$

Pendidikan agama mestinya dihargai karena hak mendidik ada pada orang tua secara kodrati, dan apabila kemudian kelompok agama-agama itu mendirikan sekolah-sekolah agama sesuai dengan keyakinan mereka, maka pemerintah harus menghargainya, apalagi sekolah-sekolah agama juga ikut terlibat aktif dalam mencerdaskan kehidupan bangsa, maka pemerintah wajib membiayai sekolah-sekolah swasta sebagaimana juga layaknya sekolah negeri. Sekolah-sekolah negeri berkewajiban memberi pendidikan dan pengajaran yang umum, sebagaimana diwajibkan pula untuk sekolah swasta, dan pendidikan dan pengajaran yang dilaksanakan di sekolah negeri ini menjadi kurikulum minimal pada sekolah swasta, dan pemerintah tidak perlu membelenggu keunikan sekolah-sekolah swasta agama.

Pada masa lalu sekolah-sekolah negeri bersifat netral karena sekolah negeri pada masa lalu hanya mengajarkan pengetahuan umum dan hal-hal yang bersifat pokok saja, dan yang diakui dapat memajukan berkembangnya budi pekerti pada umumnya. Mengenai pelajaran agama di sekolah sebenarnya pemerintah pernah menetapkan pemberian pengajaran agama di sekolah negeri sebagai budi pekerti dengan menggunakan bahan dari semua agama, jadi nilai-nilai agama yang dianut masyarakat Indonesia didorong untuk memberikan kontribusinya bagi pembangunan karakter siswa di sekolah-sekolah negeri. Kebijakan pemerintah itu membuat sekolah-sekolah negeri bersifat netral,

${ }^{20}$ Dewantara, Pendidikan, h. 189. 
atau bisa dikatakan menerima pluralisme agama-agama. Kebijakan tersebut ditetapkan karena sejak lampau pemerintah menyadari bahwa soal pengajaran agama tidak mungkin mendapatkan persetujuan yang utuh dan sempurna. ${ }^{21}$

Semangat demokrasi pendidikan terlihat jelas pada ketetapan pemerintah yang menetapkan bahwa sekolah-sekolah agama pada masa itu tidak diwajibkan untuk menyelenggarakan pengajaran agama yang berbeda dengan lembaga penyelenggara pendidikan swasta. Pendidikan dan pengajaran terhadap anakanak adalah hak orang tua secara kodrati, maka orang tua yang memasukkan anak mereka ke sekolah agama tertentu tentu saja telah memahami bahwa sekolah tersebut memiliki keunikan tersendiri berdasarkan agama tertentu, dan tentunya kurikulum yang disajikan pada sekolah tersebut jelas diketahui didasarkan pada semangat lembaga agama yang mendirikan sekolah tersebut. Jadi, sangatlah tidak beralasan jika lembaga pendidikan agama itu harus mengajarkan pengajaran agama yang berbeda dengan lembaga itu. ${ }^{22}$

${ }^{21}$ Ibid.

${ }^{22}$ Dalam perkembangan bangsa manusia dewasa ini, pendidikan tidak bisa tidak disertai dengan pengajaran. Manusia muda tidak hanya harus dibangun agar menjadi kepribadian yang sempurna dan susila, melainkan juga harus dibangun agar menjadi tenaga yang cakap untuk ikut serta memperkembangkan kehidupan negaranya. Untuk maksud ini diperlukan pengajaran. Pengajaran, terutama bagi anak-anak yang belum dewasa, tentu juga mengandung pendidikan seperti sudah dikatakan. Jadi barang siapa menyelenggarakan pengajaran, ia juga menyelenggarakan pendidikan. Inilah yang sebenarnya dilakukan negara. Dengan memberi dua cara; a. negara secara langsung mengadakan pengajaran sendiri; b. negara memperkembangkan 
Demikian juga halnya sekolah-sekolah Kristen yang dianggap memiliki sekolah-sekolah berkualitas, dan diminati banyak orang tua pada masa itu, semua isi pelajaran yang disajikan pada kurikulum sekolah tentu saja memiliki landasan teologi Kristen, karena itu sekolah-sekolah swasta agama itu tidak bisa dipaksa oleh pemerintah untuk menyelenggarakan pelajaran agama lain, dan itu sama saja mencampuri ruang privat lembaga agama itu. Pada sisi lain, pada sekolah-sekolah negeri pelajaran agama lebih diarahkan pada pelajaran budi pekerti yang merupakan nilai-nilai yang diterima semua agama. Kalaupun di sekolah-sekolah negeri diajarkan pelajaran agama, maka pelajaran agama itu tidak boleh dipaksakan ${ }^{23}$

pengajaran yang diadakan oleh usaha-usaha swasta, yang sudah jelas diserahi kepercayaan dan tugas oleh para orang tua. Mereka ini memiliki hak yang sama dengan orang-orang lain. Jadi, adanya dua cara itu dikarenakan tidak semua orang tua menyerahkan anaknya kepada pengajaran negara;banyak sekali yang menyerahkan anaknya kepada yayasan swasta pengajaran, negara dengan sendirinya juga ikut serta memberi pendidikan. Akan tetapi, yang berhak dan wajib mendidik itu sebenarnya adalah orang tua. Maka dari itu, cara menyelenggarakan dan memperkembangkan pengajaran bagi negara ada dua. a. negara secara langsung mengadakan pengajaran sendiri. b. negara memperkembangkan pengajaran yang diadakan oleh usaha-usaha swasta, yang sudah jelas diserahi kepercayaan dan tugas oleh para orang tua. Mereka ini memiliki hak yang sama dengan orang-orang lain. Jadi, adanya dua cara itu dikarenakan tidak semua orang tua menyerahkan anaknya kepada pengajaran negara;banyak sekali yang menyerahkan anaknya kepada yayasan swasta. A. Sudiardja, ed., Driyarkara (Jakarta: Gramedia Pustaka Utama, 2006) h. 422.

${ }^{23}$ Mengenai pendidikan agama di sekolah itu Dewantara memperkenalkan pemikirannya yang amat bijaksana, yaitu: 1. Janganlah menyatukan apa yang tidak dapat dipersatukan; 2. Janganlah menyatukan apa yang tidak perlu dipersatukan; 3 . Kesatuan dalam dasar dan asas, dalam pokokpokoknya cukuplah, bahkan itulah satu-satunya syarat untuk dapat menggalang 
Pancasila merupakan nilai-nilai moral minimal, artinya tidak ada agama-agama di negeri ini yang menolak nilai-nilai sebagaimana tercantum pada sila-sila dalam Pancasila, karena itu pelajaran budi pekerti atau pelajaran agama di sekolah-sekolah negeri sepatutnya tidak bertentangan dengan nilai-nilai Pancasila.

Jadi, perdebatan mengenai pelajaran agama di sekolah bukan hanya problematika masa kini, tapi telah ada sejak lama, hanya saja pemerintah pada masa lalu konsisten berpegang pada Pancasila dengan jalan demokrasinya, sehingga semua individu dan kelompok terlindungi. Sekolah-sekolah agama tidak dipaksakan untuk menyelenggarakan pelajaran agama yang berbeda dengan agama lembaga penyelenggara pendidikan itu. Demikian juga halnya yang terjadi pada sekolah-sekolah negeri, keragaman agama diterima dengan memberikan kesempatan agama-agama memberikan nilai-nilai universalnya dalam bentuk pelajaran budi pekerti.

Perdebatan mengenai pelajaran agama di sekolah sebenarnya tidak perlu terjadi di negeri ini, apalagi rakyat Indonesia adalah rakyat yang beragama, sehingga tidak ada yang menentang agama, namun memaksakan pelajaran agama di sekolah adalah sesuatu yang tidak diperlukan, apalagi memaksakan diadakannya pengajaran agama yang berbeda dengan lembaga agama sekolah-sekolah yang bernapaskan agama itu. Pendidikan nasional sepatutnya dibangun pada dasar kebangsaan bukan berdasarkan agama yang beragam dan 
berbeda. Hal ini dapat dipahami, karena untuk Indonesia yang beragam agama, suku dan budaya, usaha untuk terus mempererat rasa kebangsaan merupakan hal yang amat penting. Sebagaimana dijelaskan dalam pasal 31 UUD 1945, bahwa tiap-tiap warga negara berhak mendapat pengajaran, maka dengan demikian pemerintah wajib mengusahakan dan menyelenggarakan satu sistem pengajaran nasional yang diatur dengan undang-undang. Jelaslah bahwa segala usaha pendidikan dan pengajaran harus didasarkan pada dasar kebangsaan.

Semangat demokrasi dalam bidang pendidikan pada awalnya telah melahirkan penghargaan terhadap sekolah-sekolah swasta agama yang secara jujur diakui oleh pemerintah memiliki jasa yang besar dalam membantu perluasan pendidikan dan pengajaran bagi segenap rakyat Indonesia. Tiap aliran ideologis yang tidak bertentangan dengan Pancasila terkait dengan agama dan kemasyarakatan dilindungi haknya untuk membangun dan memelihara pendidikan yang didasarkan keyakinan dan kepercayaan masing-masing.

Pemerintah harus melindungi sekolah-sekolah agama, karena ada banyak orang tua yang memilih sekolah itu didasarkan kekhawatiran terhadap moralitas anak. Keyakinan orang tua bahwa sekolah agama itu bisa memberikan harapan bagi pembentukan moral dan karakter anak bukan hanya ada di Indonesia, tapi juga di negara-negara yang sudah maju, seperti Amerika Serikat misalnya, karena itu pilihan orang tua, dan 
seharusnya dihargai. ${ }^{24}$

Melihat pentingnya kedudukan pendidikan agama dalam gerakan pendidikan nasional seharusnya pemerintah juga mampu memanfaatkan kekuatan pendidikan agama itu dalam mencapai tujuan pendidikan nasional. Pemerintah tidak perlu memaksakan pendidikan agama yang berbeda dengan agama penyelenggara pendidikan agama itu, sebaliknya pada sekolah-sekolah negeri, keragaman agama-agama harus diakomodasi. Pendidikan agama harus diintegrasikan pada nilai-nilai Pancasila yang adalah karakter bangsa Indonesia.

Untuk mencari jalan tengah dari kontroversi yang terjadi pada Sisdiknas 2003 terkait dengan pelajaran agama, pemerintah bisa memfasilitasi sekolah-sekolah swasta yang mendasarkan pendidikannya di atas dasar pluralisme agama, demikian juga halnya pada sekolah-sekolah negeri. Pada pendidikan swasta dan negeri tersebut diajarkan agama-agama yang dipeluk oleh masyarakat Indonesia, namun, pelajaran agama itu harus didasarkan pada Pancasila. "Pendidikan agama lebih tepat disebut pendidikan keagamaan karena mencakup nilai-nilai dari semua agama yang hidup dalam masyarakat Indonesia yang bhineka itu." 25

Pelajaran agama di sekolah dalam Sisdiknas 2003 tidak akan melahirkan kontroversi apabila tidak dijadikan alat untuk

${ }^{24}$ James W. Skillen, The School Choice Controversy (Washington DC: Baker Books, 2002), h. 7-8.

${ }^{25}$ H.A.R. Tilaar, Manifesto Pendidikan Nasional (Jakarta: Kompas, 2005), h. 232. 
membelenggu kebebasan sekolah agama. Demikian juga dalam sekolah-sekolah negeri, karena nilai-nilai agama ada dalam ruang publik, maka nilai-nilai itu diterima oleh seluruh masyarakat Indonesia, sehingga tidak ada yang menolak diajarkannya pelajaran agama di sekolah. Perwujudan penerimaan nilai-nilai publik agama tersebut terlihat dengan diterimanya Pancasila sebagai dasar hidup bersama bagi semua agama yang ada di Indonesia. Penerimaan semua agama-agama terhadap Pancasila seharusnya menyadarkan pemerintah mengenai peran strategis sekolah-sekolah agama dalam mencapai tujuan pendidikan nasional, karena itu sekolah-sekolah agama itu harus dihargai keunikannya, dan pemerintah hanya perlu mengawasi mutu sekolah tersebut demi ketertiban umum. Pemerintah juga wajib memberikan subsidi pada sekolah-sekolah itu karena memiliki peran yang sama dalam mencerdaskan kehidupan bangsa.

\section{MENINJAU KEMBALI SISDIKNAS 2003 DAN JALAN DEMOKRASI PENDIDIKAN NASIONAL}

Tepatlah apa yang dikatakan Paulo Freire, "tidak ada cara lebih memadai dan efektif untuk melaksanakan proyek pendidikan selain melalui rute demokratis, dialog yang terbuka dan bersemangat. Seiring dengan bergulirnya waktu akan terbukti bahwa kekuatan politik tidak dapat digunakan untuk melayani sebagian masyarakat dengan mengorbankan sebagian masyarakat 
lainnya." 26

Penetapan sebuah Undang-undang Pendidikan Nasional tidak boleh mengabaikan proses demokrasi yang menghargai hakhak individu dan kelompok. Suara mayoritas tidak bisa mengabaikan hak-hak minoritas, apalagi menyangkut persoalan pendidikan yang berdampak pada masa depan. Sejalan dengan apa yang dikatakan Freire, tokoh pendidikan negeri ini H.A.R Tilaar pernah mengingatkan:

Dalam suatu negara demokrasi seperti Indonesia perbedaan pendapat antara golongan merupakan suatu hal yang biasa dan keharusan. Namun demikian apabila kita masuk ranah pendidikan maka berbagai arus kekuasaan yang dominan maupun yang menyuarakan pendapat alternatif perlu terdapat suatu yang tidak boleh dilupakan ialah pendidikan pertama-tama bertitik tolak dari kepentingan asasi manusia dalam suatu sistem politik. Hal ini berarti yang penting bukan sistemnya tetapi apakah kebutuhan dasar manusia dalam sistem itu dapat tercapai atau sekurangkurangnya secara optimal dapat terpenuhi. Dalam keadaan demikian tidak ada pertimbangan antara mayoritas dan minoritas seperti dalam bidang politik, akan tetapi kelompok-kleompok tersebut haruslah sepakat mengenai kebutuhan pokok atau hakiki dari manusia Indonesia dalam kehidupan berpolitik Negara Kesatuan Republik Indonesia. Kesepakatan pokok itu bersumber tidak lain dari kesepakatan bersama dalam UUD 1945. Kesepakatan minimal tersebut akan mengatasi perbedaan yang

${ }^{26}$ Freire, Pendidikan Masyarakat Kota, h. 30. 
dapat timbul dalam kepentingan bersama yang lebih luas dan luhur ialah persatuan bangsa. ${ }^{27}$

Prinsip-prinsip penting mengenai kebijakan pendidikan yakni kepentingan hak asasi manusia tampaknya diabaikan oleh para penguasa negeri ini, bisa dikatakan bahwa hadirnya Sisdiknas 2003 merupakan bukti dari tidak konsistennya pemimpin negeri ini berpijak pada demokrasi pendidikan yang menghargai hak-hak asasi setiap individu maupun kelompok agama. Lebih lanjut Tilaar mengungkapkan, "Berbagai kelemahan yang terdapat di dalam UU pendidikan nasional yaitu pengaruh kekuasaan kelompok-kelompok tertentu di DPR di dalam upaya memasukkan konsepnya mengurangi bobot nasionalisme dari undang-undang tersebut." 28

Kebijakan penetapan Undang-undang Pendidikan Nasional sejatinya bebas dari kekuasaan dan jauh dari kepentingan

27 H.A.R. Tilaar, Kekuasaan dan Pendidikan (Jakarta: Rineka, 2009), h. vii. Pada awalnya konflik ideologi mengenai Pancasila itu tidak terjadi secara terbuka dan sistematik. Pancasila tumbuh secara iuxta positif dengan ideologi-ideologi lain. Dalam dasawarsa 1950-an interaksi antara berbagai ideologi itu menjadi terbuka dan konfliktif, sebagaimana terjadi di dalam perdebatan mengenai dasar negara di dalam sidang Konstituante. Ada dua sikap terhadap Pancasila: ada yang menolak Pancasila (ideologi Islam, ideologi Barat modern sekuler), ada yang menerima Pancasila. Selanjutnya terdapat pula pemikiran yang memodifikasikan Pancasila, baik dari kalangan aliran ideologi Islam maupun aliran ideologi Barat modern sekuler. Pergumulan ideologi itu masih berjalan terus sesudah dinyatakan Dekrit Presiden Soekarno pada tanggal 5 Juli 1959. Sejak saat itu tidak terjadi konflik terbuka, akan tetapi pergumulan ideologi berjalan melalui tafsir: Pancasila ditafsirkan dengan berbagai aliran ideologi terutama ideologi keagamaan, dan ideologi Barat modern sekuler. Lihat A.M.W. Pranarkha, Sejarah Pemikiran Tentang Pancasila, (Jakarta: CSIS, 1985), h. 281.

28 Tilaar, Kekuasaan dan Pendidikan, h.50. 
kelompok agar tujuan pendidikan nasional Indonesia tidak kehilangan arah dan tetap berakar pada Pancasila dengan semangat bhineka tunggal ika. Karena itu, sistem pendidikan nasional semestinya berangkat dari sejarah lahirnya Negara Kesatuan Republik Indonesia (NKRI). Indonesia, sebagai negara yang paling terpecah-pecah di bumi ini harus terus menerus memperkuat persatuannya. Indonesia memiliki ribuan buah pulau. Belum lagi kemajemukan agama, budaya dan bahasa. Karena itu pendidikan nasional Indonesia harus mampu memperkuat kesatuan bangsa, dan secara bersamaan juga menghargai kemajemukan bangsa Indonesia. Tanpa memperhatikan semuanya itu, maka gerakan pendidikan nasional akan mengalami kebangkrutan. Setelah satu dasawarsa penetapan Sisdiknas 2003 terbukti bahwa pendidikan nasional bukannya makin lebih baik, sebaliknya terus mengalami keterpurukan, ini mestinya menyadarkan pemerintah dan semua elemen bangsa bahwa ada yang salah dengan pemberlakuan Sisdiknas 2003 itu.

Kegagalan pendidikan nasional ini berakibat luas, yakni membawa negeri ini pada krisis multi-dimensi, sebagaimana diungkapkan Soediharjo:

Tampaknya banyak di antara kita yang tidak menyadari bahwa sampai sekarang kita masih jauh dari berhasil dalam tugas mewujudkan suatu tata kehidupan Negara bangsa Indonesia yang merdeka, modern, demokratis, berkeadilan sosil, berke-Tuhan yang maha esa, dan menjunjung tinggi HAM. Kenyataan yang kita hadapi adalah suatu proses transisi yang kurang jelas arah sasarannya, baik di bidang politik, ekonomi, serta aspek sosial 
budaya dan lainnya, baik ilmu pengetahuan dan teknologi maupun kebudayaan. Yang terjadi sekarang ini bahkan adalah krisis multidimenasi. ${ }^{29}$

Salah satu hal penting yang menjadi kegagalan pendidikan nasional adalah tidak dilibatkannya masyarakat dalam pembangunan sistem pendidikan nasional. Sebagai sebuah negara demokrasi mestinya setiap individu di negeri mempunyai hak yang sama untuk terlibat dalam menentukan arah pendidikan nasional, tidak boleh ada individu atau kelompok yang terabaikan. Terabaikannya interest individu atau kelompok dalam menyelenggarakan pendidikan agama sesuai dengan agama yang dianutnya menjelaskan bahwa jalan demokrasi belum dipegang teguh. ${ }^{30}$

Kontroversi sekitar Sisdiknas 2003 yang mengabaikan prinsip demokrasi pendidikan mestinya menjadi pelajaran penting untuk semua pemangku kepentingan di negeri ini. Kepentingan kelompok dan partai politik harus dikesampingkan ketika akan merumuskan kebijakan sistem pendidikan nasional. Dengan demikian dapat diharapkan hadirnya Undang-undang Pendidikan Nasional yang menjadi milik seluruh bangsa. Sehingga setiap individu dan kelompok dapat menyumbangkan sesuatu yang

${ }^{29}$ Soedijarto, "Mencerdaskan Kehidupan Bangsa dan Memajukan Kebudayaan Nasional Adalah Misi yang Harus Dilaksanakan Melalui Diselenggarakannya Satu Sistem Pendidikan Nasional (Makalah Kuliah UNJ: Jakarta, 2014).

${ }^{30}$ Lihat John Dewey, Democray and Education (Mineola, New York: Dover Publication, 2004), h. 95. 
terbaik bagi kepentingan bangsa Indonesia. Pendidikan agama, dengan sekolah-sekolah agamanya yang tersebar di seantero negeri ini harus tetap dilindungi untuk memberikan kontribusi terbaiknya. Untuk itu pemerintah harus mengambil jalan demokrasi pendidikan, dan bukannya menggunakan cara-cara yang otoriter, atau juga berpihak pada dominasi mayoritas. Proses pendidikan yang demokratis adalah jalan terbaik untuk membangun masyarakat Indonesia menuju masa depan gemilang. Untuk itu meninjau kembali Sisdiknas 2003 adalah jalan yang bijaksana. 